\title{
HOME BIRTH: UNDERSTANDING THE REASONS FOR THIS CHOICE
}

\author{
Clara Fróes de Oliveira Sanfelice ${ }^{1}$, Antonieta Keiko Kakuda Shimo ${ }^{2}$
}

\footnotetext{
${ }^{1}$ Doctoral student, Programa de Pós-Graduação em Enfermagem at the Universidade Estadual de Campinas (UNICAMP). Nurse of Centro de Atenção Integral a Saúde da Mulher. Campinas, São Paulo, Brazil. E-mail: clara_sanfelice@yahoo.com.br

${ }^{2}$ Ph.D. in Nursing. Professor. Faculdade de Enfermagem, UNICAMP. Campinas, São Paulo, Brazil. E-mail: akkshimo@fcm. unicamp.br
}

\begin{abstract}
This qualitative, exploratory and descriptive study aimed to understand the reasons that underlie the choice of homebirth. The information was captured through semi-structured interviews, applied between February and March 2014, recorded and transcribed. The sample obtained by saturation of data was composed of 14 women who had at least one experience of home birth, planned and attended in the previous year in the city of Campinas, state of São Paulo, Brazil, and region. The discussions were analyzed according to the method of Bardin's content analysis. The results gave rise to two categories: to gain information so as to be able to make an informed choice, and to be against the model of hospital care. The reasons listed show that the acquisition of knowledge is a basic condition to support the decision to give birth at home, in addition to revealing these women's great dissatisfaction with the current institutionalized model of care during childbirth.
\end{abstract}

DESCRIPTORS: Midwifery. Humanized delivery. Obstetric nursing. Home childbirth.

\section{PARTO DOMICILIAR: COMPREENDENDO OS MOTIVOS DESSA ESCOLHA}

\begin{abstract}
RESUMO: Pesquisa qualitativa, exploratória e descritiva, que objetivou compreender os motivos que sustentam a escolha pelo parto domiciliar. As informações foram captadas por meio de entrevistas semiestruturadas, aplicadas entre fevereiro e março de 2014 , gravadas e transcritas. A amostra, obtida por meio de saturação de dados, foi composta por 14 mulheres que tinham pelo menos uma experiência de parto em casa, planejado e assistido, no último ano, na cidade de Campinas, São Paulo, e região. As falas foram analisadas segundo o Método de Análise de Conteúdo. Os resultados originaram duas categorias: informar-se para fazer uma escolha consciente e ser contra o modelo de atendimento hospitalar. Os motivos elencados evidenciam que a aquisição do conhecimento é condição básica para respaldar a decisão de parir em casa, além de revelar uma grande insatisfação dessas mulheres com o atual modelo institucionalizado de atenção ao parto.
\end{abstract}

DESCRITORES: Tocologia. Parto humanizado. Enfermagem obstétrica. Parto domiciliar.

\section{PARTO DOMICILIAR: COMPRENDIENDO LAS RAZONES DE ESTA ELECCIÓN}

RESUMEN: Investigación cualitativa, exploratoria y descriptiva que tuvo como objetivo comprender las razones que subyacen la elección del parto domiciliar. La información fue capturada a través de entrevistas semi-estructuradas, aplicadas entre febrero y marzo de 2014, grabadas y transcritas. La muestra obtenida por saturación de datos se compone de 14 mujeres que habían tenido al menos una experiencia de parto en casa, planificado y asistido en el último año en la ciudad de Campinas, São Paulo, Brazil. Las conversaciones fueran analizadas según el método de análisis de contenido de Bardin. Los resultados llevaron a dos categorías emergentes: informar para hacer una elección consciente y estar contra el modelo de atención hospitalaria. Las razones mencionadas muestran que la adquisición de conocimientos es una condición básica para apoyar la decisión de dar a luz en casa, además de revelar una gran insatisfacción con el modelo actual de atención institucionalizada al nacer, por estas mujeres.

DESCRIPTORES: Tocología. Parto humanizado. Enfermería obstétrica. Parto domiciliário. 


\section{INTRODUCTION}

Brazil shows fairly concerning indicators in relation to perinatal care. The hegemonic technocratic obstetric model results in an unjustifiable rate of surgical births (cesareans) and in rates of maternal and neonatal mortality which remain fairly high, with perinatal indicators worse than those found in other countries with levels of socioeconomic development which are equal to or inferior to those of Brazil. ${ }^{1-2}$

In addition to this, $25 \%$ of the women who had a normal birth reported having suffered some type of mistreatment or obstetric violence, according to a study undertaken in the beginning of $2012 .^{3}$

Given this context, one can observe a growing, although timid, movement, in which some women have opted to experience giving birth in the home environment.

Despite being a practice which is recognized and is already legitimated in various countries, such as Canada, Holland and Australia, ${ }^{4-6}$ the practice of homebirth, in Brazil, still represents a modality of care during childbirth which is still in its early stages. The current statistics show that a little over $98 \%$ of births take place within health institutions. ${ }^{7}$ The remainder still includes those births which took place either on the way to the health institution, or at home when this was not planned. This demonstrates that the proportion of homebirths - planned as such, and assisted by trained professionals - in present-day society, remains very low.

Curiously, however, the discussions regarding homebirth, although this represents a very small rate when compared to the number of total births, has given rise to various debates and much questioning at the present time, whether in the political, academic or scientific areas. The great polemic which involves homebirth occurs due to the fact that this is considered, by contemporary medicine, to be a retrograde act, given the numerous advances and resources available to healthcare, placing the health of the woman and the newborn at risk. ${ }^{8}$

This fact demonstrates that the reasons which lead a woman to choose to give birth at home - foregoing technology, modernity and supposed safety found nowadays in hospitals/ maternity units - remain largely incomprehensible to society. ${ }^{8}$

As a result, this study aims to shed light on the reasons listed by the women who gave birth at home and which supported their decision - so as to increase understanding regarding this littleexplored phenomena, which is on the ascent in our society.

\section{METHODS}

This qualitative, exploratory and descriptive research aimed to uncover the reasons for which women are currently choosing to give birth at home. The data were collected in February-March 2014 using an instrument which contained data referent to the sociodemographic and obstetric characterization, along with a semistructured interview made up of 11 open questions. The interviews were recorded and immediately transcribed, lasted an average of 25 minutes, and were held in the women's homes.

The participants were selected through the suggestion of names provided by teams which work in attending homebirths in the city of Campinas (in the state of São Paulo) and the surrounding region. Among all the participants invited, nobody declined to participate in the study. The sample was made up of 14 women who had at least one experience of a planned birth attended at home, in the preceding 12 months, in the above-mentioned location. The number of participants was determined by sampling by saturation.

In order to develop this article, part of the data was extracted from a larger qualitative study, which aimed to understand the social representations of the women who chose to give birth at home, and which complied with the directives and regulatory standards for research involving human beings, found in Resolution 466 of 12/12/2012 of the Brazilian National Health Council, whose approval is found in Opinion $n$. $331.743 / 2013$.

The treatment and analysis of the data took place through the process of content analysis, which is made up of three stages: 1) pre-analysis; 2) exploration of the material and 3) treatment of the results, inference, and interpretation. ${ }^{9}$

Initially, all the material collected was organized in order to begin the next stage of the study, that is, data analysis. This process of organization took place through four stages: 1) skim reading; 2) choice of the documents; 3 ) elaboration of hypotheses and objectives; and 4) referencing of the rates and elaboration of the indicators. Following that, the material was explored, an important stage in order to allow, or not, the richness of the 
interpretations and inferences. In this stage, the coding, classification and categorization are basic procedures. The last phase relates to the treatment of the results, inference, and interpretation. At this point, information is condensed and emphasized for analysis, culminating in the inferential interpretations; this is the point of intuition, of reflexive and critical analysis.

After the entire process of analysis, the data gave rise to two categories: gaining information for oneself, in order to make an informed choice, and being against the model of hospital assistance. In order to ensure confidentiality of the reports, the participants were identified using the names of flowers.

\section{RESULTS AND DISCUSSIONS}

\section{Sociodemographic and obstetric characterization}

In relation to the sociodemographic characteristics, the women's age range varied from 25 to 39 years old, the interval between 25-29 years old predominating $(50 \%)$. All the participants had completed higher education and were married and/or in a stable relationship. Most stated that they undertook paid work (78.6\%), and had a family income $\geq 10$ minimum salaries $(50 \%)$ and health insurance $(92.9 \%)$.

In relation to the obstetric data, most of the women were nulliparous (57.1\%), and among the multiparous women, the majority had a vaginal birth $(83.3 \%)$, in-hospital (83.3\%), prior to the experience of the homebirth.

\section{Gaining information for oneself in order to make an informed choice}

Subsequent to the analysis of the reports, it was possible to understand that the option for the homebirth occurred after the point at which the women not only became aware of this new mode of attendance, but immersed themselves in seeking information on this possibility.

Firstly, to know the choice that she is making, to have information, you can't go for a homebirth, or even opt for a cesarean, for example, without having the information. So it's all sorts of information, of the risks, the benefits, the planning, how you can do things. I think the main one is information. [...] I was scared, but after I found out what the risks were, what you could do in cases of emergency, [...] all this made me opt for the homebirth. [...] After I had studied a little, I read a little more about homebirth, I became quite calm about making this choice (Orchid).

I think it is fundamental for the woman to read. [...] I think it is important for women to read, study, chase things up, understand the phases of childbirth, anything that might be useful, and what mightl not, [...] If you're prepared, you can take it on. [...] (Calla Lily).

[...] You must find out quite a lot, watch videos, and talk with people who have already had this experience. (Cherry tree).

First of all is information, I think that you have to find out a lot (Lotus flower).

According to the recently-published data from the largest study on birth and childbirth in Brazil, ${ }^{1} 70 \%$ of Brazilian women intend to have a normal birth at the beginning of their pregnancy. However, one can observe that over the course of the pregnancy the decision changes in relation to the type of birth, culminating with rates of $53 \%$ of cesarean operations in the public health network, and $83 \%$ in the supplementary health sector, which cannot be explained by the occurrence of problems and complications. ${ }^{1}$

This information points to the fact that women are gradually induced to abdicate from their choices regarding the type of birth, and/or are convinced to change their opinions, through the imposition of unrealistic rationales, gradually and in a poorly-explained way, undermining these women's confidence for the process of giving birth, whether in the institutional environment or not.

The health professional is ethically and legally obliged to offer clear and complete information regarding the care, and to provide the client with the opportunity to participate in the decisions based on the information received. ${ }^{10}$ In this way, she must promote the woman's autonomy in the birth, beginning with information which is scientifically based and non-tendencious, such that they may make shared decisions which are adequately based. ${ }^{11}$

Encouraging women's informed decisionmaking is to value their ability to decide; to respect their right to their own body and to autonomy; to detect new paths and ways of acting, as a professional; to promote their human rights and recover care which is centered on the woman's needs. ${ }^{11}$

The woman's choices and decisions regarding the type of birth result from a process which involves multiple factors, such as education, socioeconomic conditions, life history, stories re- 
garding birth which she has heard or experienced, knowledge regarding the conditions of childbirth care and access to information which is generally inaccessible to the majority of women. ${ }^{11}$

Regarding homebirth, it seems that this option is related to a higher educational level, reflected in access to information and biomedical knowledge, allowing critical analysis of the obstetric practices and the possibility to argue for, and stick to, the decision to give birth at home. ${ }^{12}$

This means that these women enter into contact with the information offered by studies and current scientific evidence, take possession of this knowledge, have the conditions to question current practices and, based on this, feel safe to make an informed choice, in full possession of the facts, and well-founded.

The international literature has been fairly compelling in demonstrating that the obstetric and perinatal results are similar when the places in which women give birth are compared, deconstructing the currently-dominant concept in Brazil that homebirth offers greater risks to women and to newborns in relation to hospital birth. ${ }^{13-17}$

The results show that homebirth is associated with low rates of obstetric interventions, and that there is no increase in the rates of perinatal mortality. ${ }^{13-15}$ The Brazilian literature reinforces the good results, indicating a reduced rate of hospital transference, need for cesareans, perineal trauma and use of drugs, both during childbirth and in the postpartum period..$^{18-19}$

As a result, these women perceive that lowrisk homebirth, planned, and attended by trained professionals, presents favorable results and may be considered to be as safe as hospital birth. This information strongly contributes to the credibility of this mode of care and becomes the mainstay for decision-making, which seems reasonably relevant.

[...] knowledge of the process, is taking away your doubts, it is to not be scared of the unknown, so the issue of the unknown is to know it! [...] Through this knowledge, the woman is empowered, and it is clear, well-founded empowerment. [...] It is to base oneself in knowledge, women need to know what is going to happen, these things give you plenty of structure for giving birth [...] They give you strength for making your own decision, as a woman (Lily).

In this way, women use the information acquired not only as a basis for supporting their option, but also in order to experience the event naturally and to recognize their rights, regardless of where the birth takes place.

Information, in my opinion, is an essential factor, [...] so, if you have the information beforehand, it isn't something scary, it is just something as you foresaw it, as expected. [...] So I think that what is actually missing is information, because when the time comes, it is even the case that if you go for a hospital process you can say 'no', you have the conditions to do that (Daisy).

The search for information was presented in different ways by the women in this study, with important emphasis for the participation in the childbirth preparation groups. [...] the meetings I went to, the meetings for couples, were very important for my husband (Carnation).

[...] groups for discussing ideas, exchanging experiences, doubts, for clarifying doubts, [...] we attended the pregnant women's group, and that gave me a lot of strength, those doubts, learning to deal with them, and creating doubts that you hadn't had yet, it is to do with finding out what the hospital environment is like, what childbirth is like, this exchanging of experiences develops and supports you for the moment of birth (Lily).

[...] the really big influence came from the doula, she helped us a lot with this process of information... but also because we went looking, we always wanted to search for information (Daisy).

[...] she suggested a book for me to read [the doctor], and that had some accounts of homebirth, there in the beginning I began to attend the group, [...] what really made me take the decision was the seminar we heard from the obstetrician, she explained what risks existed, which risks didn't exist, she was very frank in the lecture (Lotus flower).

[...] but what helped me most, apart from my husband's support, was the group, which was very important, I think that everybody should participate so as to make better decisions to guide oneself better (Hydrangea).

I was sure that I would have a cesarean, arranged for a specific time, and then I began, at the suggestion of a friend, to attend the group - but I didn't know what it was about. [...] And so I began to go, and it was an absolute shock, from the beginning, in the very first meeting I said: 'My God, I think that everything is wrong, I think I need to look again at everything that I think, that I believe! [...] It stopped being something that was frightening for me, and became something which was very natural [...] Because of all this information which we learned, we stopped being scared of this, in fact we began to be scared of the cesarean! (Rose).

As a result, the choice for a planned home- 
birth is growing in our society, above all because more and more women have shared their experiences of giving birth through participation in support groups and using tools of the Internet, such as social networks and blogs. ${ }^{20}$

The educational process undertaken in the pregnant women's group makes it possible to break myths, prepare for the birth, for parenthood, and provides the couple with greater security and autonomy, leading to changes in attitudes and behaviors. $^{21}$

The potential impact which childbirth preparation groups can offer, not only for women, but for society as a whole, is evidenced. Their existence, therefore, should be strongly encouraged, both in the public and private sectors, such that they may represent instruments for change in the current obstetric scenario.

In conjunction with this factor, one can perceive that acquiring knowledge, on the part of the women and their families, has become a strong tool for supporting decision-making, demonstrating that this may be the most appropriate path for the claiming and conquest of a model of care during childbirth which is safer and more respectful in the Brazilian context.

\section{Being against the model of hospital attendance}

This category showed that the women who participated in this study do not agree with the model of attendance for birth proposed in the hospital environment, which predominates in our society. The reports show, with great clarity, that the participants question the procedures and routines imposed by the institution, that they do not identify with the logistics of the attendance offered, and strongly associate the hospital environment with the concept of illness, which seems not to match the event of childbirth, in these women's opinion.

[...] it is a hostile environment, in the sense that you go to hospital when you are sick! (Rose).

I really didn't want the hospital environment, I already think it is an environment strongly to do with illness, I think that has nothing to do with birth! (Sunflower).

Unfortunately, the currently-predominant model of care has many professionals who still hold on to obsolete and aggressive notions and practices in attending vaginal births in the public sector, and, in the private sector, adhere to the misogynist concept that vaginal birth is primitive, inconvenient, unbearably painful, repulsive in its more bodily aspects, and harmful to the woman's sexual health, and that it must, therefore, be prevented whenever possible. ${ }^{17}$ In the light of this frightening context, what are the options for women who wish to give birth in a free, respectful and aware way?

[...] it is impossible for you to go to hospital and have a humanized birth. [...] I would have been cut, or at least have undergone various interventions which I do not want in any way whatsoever (Daisy).

[...] I didn't know that things were so bad here, that there were so many cesareans and interventions (Hydrangea).

The criticism of the current obstetric model of care has been the subject of many debates. Women are increasingly aware of the scientific knowledge which has been widely disseminated with the advent of the Internet ${ }^{22}$ and, on taking possession of the information, previously monopolized by the doctor, relativize the professional's authority, assert their dissatisfaction with what is on offer, reinterpret their experience, denounce the violence to which they feel they are subjected and claim their right to informed choice and refusal. ${ }^{23}$

[...] I got out [of the pool], I didn't feel well, I don't want it! You think that if it had been in hospital I would've said 'no'? (Hydrangea).

In addition to this, this broad dissemination of the information allows women to find out about the reality in other countries, where public policies promote spontaneous birth, centered on the woman, and enter into the world of scientific data and issues related to legislation, which triggers a profound culture shock, ${ }^{22}$ as well as deep dissatisfaction with the model offered in the vast majority of Brazilian institutions.

[...] when you arrive in the hospital you have to confront all that bureaucracy, because in Brazil you are not prepared for normal birth, you arrive there, they want you to fill out a pile of documents before going in and you are not allowed to leave it... leave it until afterwards! (Rose).

The inquiry on labor and birth ${ }^{1}$ showed that, among the pregnant women in the sample who had vaginal births, the predominance was observed of a medicalized model of care, as the majority of them were subjected to excessive interventions, were restricted to the bed and not encouraged to walk, did not eat during labor, used drugs to accelerate the contractions (oxytocin), were subjected 
to episiotomy, and gave birth lying on their backs, very often with somebody pressing on their belly (the Kristeller maneuver). Only 5\% of the total of this sample experienced birth without the abovementioned interventions. Hence, this study asserts that the medicalization of birth is a practice which is disseminated throughout Brazil, and that the predominant institutionalized model of care during childbirth is, unfortunately, maintained by ignoring the best scientific evidence available. ${ }^{1}$

After this process of knowledge of the model of care practiced in the hospital space, the same comes no longer to be seen as an environment which is appropriate and/or compatible with the experience of natural birth, frustrating mothers' expectations. At this point, one can perceive that all the knowledge acquired makes the home environment an option consistent with that desired by these women.

[...] you go to a hostile environment, to an environment which has a routine, and you don't necessarily fit into that routine, and at home, you have your routine! (Begonia).

[...] in hospital it is much harder, it is a colder environment, no matter the extent to which you are with a humanized professional, you have some things, to do with the hospital per se, some rules which you have to follow... So all this is rather a nuisance (Orchid).

[...] you are in a noisy, stressful environment, with people irritating you. Of course it is going to hurt more. So, if you are giving birth, being respected, in your environment, with you in charge of the situation, it is much easier to deal with (Lily).

In their accounts, these women point to various factors which demonstrate the dissatisfaction with the hospital space for giving birth: separation of the experience with other family members (husband and children), lack of intimacy and embracement, the coldness and impersonality of the relationships, not being familiar with the environment, external interferences in the process of birth, separation between mother and baby upon being born, undertaking of procedures which are not recommended during the attendance to the newborn (immediate cutting of the umbilical cord, delay in making skin-to-skin contact and the first breast-feed), as well as excessive bureaucracy which is inconsistent with the event of labor (signing documents and filling out forms, among others).

In conjunction with these factors, another significantly relevant aspect, which emerged in this category, was fear of feeling oneself to be coerced within the hospital environment. This may be explained by the fact that, for many professionals, it seems there is something particularly wrong in women who wish to have a normal birth, given that the most obvious thing would be for them to desire a cesarean. ${ }^{22}$

In the light of this concept, many teams show total technical and staff-related lack of preparation for monitoring women who wish to give birth physiologically, with the solution suggested being the management of the normal birth in an extremely medicalized and invasive way or the induction of a surgical birth.

The lack of autonomy and the fear of not being in control during the experience of birth awakens in the women the feeling that it is necessary to outline strategies for fleeing this context. The desire blossoms to be accompanied by professionals who believe in their potential for giving birth, who are genuinely favorable to experiencing normal and physiological birth, and who respect the autonomy and the exercising of shared decision-making for taking decisions.

[...] we see that in hospital nowadays, you can't manage to have much control of your body, the professionals don't respect you much, and don't respect your choices much either (Orchid).

[...] at home, we managed to spend much more time with just us two, the girls [the nurses] were here, keeping us company, but always very delicately, very tenderly, they didn't keep coming up to speak to us, there were no papers to sign, there was nothing happening apart from the birth, which is, after all, the main event! (Cherry tree).

[...] I was in my house, I felt safe, I didn't have any type of external interference, from people who I didn't know coming into the room to examine me, they were people I knew, I felt free to express myself, just as I wanted [...] (Rose).

It is estimated that in Brazil nearly 1 million women per year are subjected to cesareans without appropriate obstetric justification, losing the opportunity to be the protagonists in the birth of their children, and being exposed, with them, to greater risks of mortality and morbidity - and unnecessarily increasing the resources spent on health. ${ }^{1}$

This sad observation explains the fear that many women have of being coerced in the hospital environment to accept unwanted procedures, undergoing a process of birth which is medicalized and violent, which creates large possibilities of an outcome which is dissatisfactory and unfavorable to the mother and/or baby. 
I was always scared of them ending up inducing a cesarean: that I wouldn't be able to manage, you are too young, you're going to suffer a lot! (Begonia).

[...] I was always scared of having my baby in hospital, [...] They take (the baby), do a load of things and the baby ends up not having this contact with the mother, [...] The umbilical cord is another thing which frightened me quite a bit, because they cut the cord before it stops pulsing, [...] And I wanted it to stop pulsing, and in the hospital they don't have this care (Daisy).

The medicalization of the birth, as a result of the social medicalization, has been described as a complex sociocultural process which transforms experiences, suffering and pain previously managed in the family or community environment itself into medical necessities. As a result, medicalization is a cultural transformation which influences the capacity for autonomous facing of the experience of giving birth, given that it entails excessive dependence, heteronomy and the abusive use of cesareans. ${ }^{24}$

This context also justifies the option indicated by these women, for homebirth. It shows that giving birth at home is definitively not related to lack of information or to faddism, as one may hear in some current debates on the issue. Much to the contrary, however, the statistics, the scientific data, and the evidence available are fairly solid and able to explain the rationales involved in making the decision to give birth at home.

\section{CONCLUSIONS}

The practice of giving birth at home seems to be directly related to acquiring knowledge which involves the Brazilian obstetric model of care, including the technical, scientific and legal aspects of all the regulations, procedures and routines imposed by the institutionalized care.

When the women enter this world, no longer as passive subjects receiving information, but rather with an active stance which is questioning, critical and reflexive regarding what is offered to them, many historically-consolidated concepts come to be seen from a different angle, leading to different behaviors and attitudes on the part of these women.

As a result, the option of giving birth at home doesn't seem to represent a strategy related to faddism, disinformation or rebelliousness. Women show a high level of knowledge, are consistent in their discourses, and are very clear that the lack of information represented the main obstacle for this decision. They not only defend homebirth, but also reveal, in a parallel way, all the constraints and setbacks involved in the institutionalized care.

One can, therefore, conclude that disseminating the knowledge and allowing access to safe, non-tendentious information for all women should become a basic premise for the professionals involved in obstetric care, and should be understood as a valuable tool for transforming our current scenario of labor and birth.

\section{REFERENCES}

1. Escola Nacional de Saúde Pública. Fundação Oswaldo Cruz. Nascer no Brasil - inquérito nacional sobre parto e nascimento. In: Sumário Executivo Temático da Pesquisa [online]. 2014 [acesso 2014 jul 22]. Disponível em http://www.ensp.fiocruz. br/portal-ensp/informe/site/arquivos/anexos/ nascerweb.pdf

2. Dias MAB. Humanização do parto: política pública, comportamento organizacional, profissional e ethos. Cad Saúde Pública 2011; 27(5):1042-3.

3. Fundação Perseu Abramo. Núcleo de Opinião Pública. Gravidez, filhos e violência institucional no parto. In: Mulheres brasileiras e gênero nos espaços público e privado: pesquisa de opinião pública [online]. São Paulo (SP): Fundação Perseu Abramo; 2010 [acesso 2014 jul 28]. Disponível em: http:// csbh.fpabramo.org.br/node/7247

4. Walsh S, Blijden J. Having a baby in Netherlands [online]. The Hague: Access; 2012. [acesso 2013 Nov 21]. Disponível em: http://www.access-nl. org/media/13946/guide_having_a_baby_in_the_ netherlands.pdf

5. Ontario Hospital Association (OHA). College of Midwives of Ontario and Association of Ontario Midwives. Resource manual for sustaining quality midwifery services in Hospitals. Ontário (CA): Ontario Hospital Association; 2010.

6. Government of South Australia. Department of Health. Planned birth at home: policy [online]. Adelaide (AU): Government of South Australia; 2007 [acesso 2013 mar 10]. Disponível em: http:/ / www. health.sa.gov.au/PPG/Default.aspx?tabid=189

7. Ministério da Saúde (BR). Rede Interagencial de Informações para a Saúde [Internet]. Indicadores e dados básicos, Brasil, 2011: indicadores de cobertura. Proporção de partos hospitalares [online]. Brasília (DF): MS; 2012 [acesso 2014 ago 01]. Disponível em: http://tabnet.datasus.gov.br/cgi/tabcgi. exe?idb2012/f07.def

8. Sanfelice CFO, Shimo AKK. Home childbirth: progress or retrocession? Rev Gaúcha Enferm. 2014 Mar; 35(1):157-60. 
9. Bardin L. Análise de conteúdo. Lisboa (PT): Edições 70; 2002.

10. Sodré TM, Bonadio IC, Jesus MCP, Merighi MAB. Necessidade de cuidado e desejo de participação no parto de gestantes residentes em Londrina-PR. Texto Contexto Enferm. 2010; 19(3):452-60.

11. Sodré TM, Merighi MAB, Bonadio IC. Escolha informada no parto: um pensar para o cuidado centrado nas necessidades da mulher. Cienc Cuid Saude 2012; 11(supl):115-20.

12. Feyer ISS, Monticelli M, Knobel R. Perfil de casais que optam pelo parto domiciliar assistido por enfermeiras obstétricas. Esc Anna Nery. 2013; 17(2):298-305.

13. Jonge A, Van der Goes BY, Ravelli AC, AmelinkVerburg MP, Mol BW, Nijhuis JG, et al. Perinatal mortality and morbidity in a nationwide cohort of 529.688 low-risk planned home and hospital births. Int J Obstet Gynecol. 2009; 116(9):1177-84.

14. Jonge A, Mesman JAJM, Manniën J, Zwart JJ, van Dillen J, van Roosmalen J. Several adverse maternal outcomes among low risk women with planned home versus hospital births in the Netherlands: Nationwide cohort study. BMJ. 2013 Jun 13; 346:f3263.

15. Birthplace in England Collaborative Group. Perinatal and maternal outcomes by planned place of birth for healthy women with low risk pregnancies: the Birthplace in England national prospective cohort study. BMJ. 2011 Nov 23; 343:d7400.

16. Wax JR, Lucas FL, Lamont M, Pinette MG, Cartin A, Blackstone J. Maternal and newborn outcomes in planned home birth vs planned hospital births: a metaanalysis. Am J Obstet Gynecol. 2011; 204(4):7-13.
17. Van Der Kooy J, Poeran J, de Graaf JP, Birnie E, Denktasş S, Steegers EA et al. Planned home compared with planned hospital births in the Netherlands: Intrapartum and early neonatal death in low-risk pregnancies. Obstet Gynecol. 2011; 118(5):1037-46.

18. Koettker JG, Brüggemann OM, Dufloth RM, Knobel $\mathrm{R}$, Monticelli M. Resultado de partos domiciliares atendidos por enfermeiras de 2005 a 2009 em Florianópolis, SC. Rev Saúde Publica 2012; 46(4):74750.

19. Colacioppo PM, Koiffman MD, Gonzalez Riesco ML, Schneck CA, Osava RH. Parto domiciliar planejado: resultados maternos e neonatais. Rev Enfern Ref. 2010; 3(2):81-90.

20. Ministério da Saúde(BR). Programa deHumanização do Pré-Natal e Nascimento (PHPN). Caderno Humaniza SUS: humanização do parto e nascimento. Brasília (DF): MS; 2014.

21. Zampieri MFM, Gregório VRP, Custódio ZAO, Regis MI, Brasil C. Processo educativo com gestantes e casais grávidos: possibilidade para transformação e reflexão da realidade. Texto Contexto Enferm. 2010; 19(4):719-27.

22. Diniz CSG. O renascimento do parto, e o que o SUS tem a ver com isso. Interface. 2014; 18(48):217-20.

23. Salgado HO, Niy DY, Diniz CSG. Groggy and with tied hands: the first contact with the newborn according to women that had an unwanted c-section. J Human Growth Development. 2013; 23(2):190-7.

24. Leão MRC, Riesco MLG, Schneck CA, Angelo M. Reflexões sobre o excesso de cesarianas no Brasil e a autonomia das mulheres. Ciênc Saúde Coletiva. 2013; 18(8):2395-400. 